\section{'Maurine Blue' Lisianthus [Eustoma grandiflorum (Raf.) Shinn.]}

\author{
Brent K. Harbaugh and John W. Scott \\ Gulf Coast Research and Education Center, University of Florida, 5007 60th \\ Street East, Bradenton, FL 34203
}

Additional index words. heat tolerant, high temperature, rosette, potted flowering plants

\begin{abstract}
Seedlings of commercial lisianthus cultivars form rosettes when grown at 25 to $28^{\circ} \mathrm{C}$ (Harbaugh et al., 1992; Ohkawa et al., 1991). Rosetted plants have a basal cluster of leaves; very short internodes, typical of biennials; and do not bolt or flower for 3 to 6 months without being exposed to 3 to 4 weeks at $\leq 15$ to $18^{\circ} \mathrm{C}$ to reverse heat-induced rosetting (Ohkawa et al., 1994; Pergola, 1992). Semirosetted plants develop when seedlings are grown at a constant 22 to $25^{\circ} \mathrm{C}$ or at $<22{ }^{\circ} \mathrm{C}$ nights with $>28$ ${ }^{\circ} \mathrm{C}$ days. Although semirosetted plants have one or more side shoots that may elongate and flower, they flower unpredictably and are of poor quality as cut flowers or potted plants. Thus, commercial production of lisianthus for late spring or summer sales is limited by high temperatures in many areas of the United States and other countries. Fall plug production, to produce flowering plants for early spring sales, also is difficult due to rosetting of plugs caused by the interaction of high temperatures and short days (Harbaugh, 1995). 'Maurine Blue' is a heat tolerant lisianthus developed at the Univ. of Florida's Gulf Coast Research and Education Center, Bradenton. Seedlings have been produced at 28 to $31^{\circ} \mathrm{C}$ without rosetting.
\end{abstract}

\section{Origin}

'Maurine Blue' is the $F_{1}$ hybrid resulting from crossing inbred lines GCREC-P76 and GCREC-9104 (Fig. 1). GCREC-P76 was an $\mathrm{F}_{4}$ selection of a cross between GCREC-8-57 and 'Yodel Pink'. GCREC-8-57 was a selfpollinated plant $\left(S_{1}\right)$ selected from 'Tosen' for its ability to flower in the summer $\left(35^{\circ} \mathrm{C}\right.$ day $)$ and for its basal and lower branching characteristics. The 'Yodel Pink' plant was a selection that flowered after seedlings were exposed to $28^{\circ} \mathrm{C}$ in a growth chamber. In addition to its heat-tolerant characteristics, it was used because of its bell-shaped flowers and overlapping petals. Growing conditions used to select $\mathrm{F}_{1}$ to $\mathrm{F}_{4}$ GCREC-P76 seedlings for resistance to heat-induced rosetting were 1) production during summer months under

\footnotetext{
Received for publication 17 Nov. 1995. Accepted for publication 18 June 1996. Florida Agricultural Experiment Station Journal Series R-04864. We thank Nancy West for her excellent technical support. The cost of publishing this paper was defrayed in part by the payment of page charges. Under postal regulations, this paper therefore must be hereby marked advertisement solely to indicate this fact.
}

greenhouse conditions at $\geq 35^{\circ} \mathrm{C}$ day in the $\mathrm{F}_{1}$; 2) exposure of 3 - to 4-week-old seedlings to 28 ${ }^{\circ} \mathrm{C}$ for 4 weeks in the $\mathrm{F}_{2}$ and $\mathrm{F}_{3}$; and 3 ) exposure of 17-day-old seedlings to $31^{\circ} \mathrm{C}$ for 5 weeks in the $\mathrm{F}_{4}$. GCREC-9-104 was identified after five generations of self-pollination $\left(\mathrm{S}_{5}\right)$ from 'Blue Poppy'. Growing conditions used to select $S_{1}$ to $S_{5}$ generations for heat tolerance were 1 ) production of plants under summer greenhouse conditions in the $S_{1}$ and $S_{2} ; 2$ ) exposure of seedlings to $28^{\circ} \mathrm{C}$ for 4 weeks in the $S_{3}$ and $\mathrm{S}_{4}$; and 3) exposure of seedlings to $31^{\circ} \mathrm{C}$ for 5 weeks in the $\mathrm{S}_{5}$.

\section{Description}

'Maurine Blue' tolerated greenhouse production temperatures year-round in Bradenton in 1994 with $0 \%$ to $6 \%$ rosetting (Table 1) even though day maximum summer and fall readings reached $35^{\circ} \mathrm{C}$ and nights were rarely below $22^{\circ} \mathrm{C}\left(18^{\circ} \mathrm{C}\right.$ minimum). During this evaluation, 'Maurine Blue' plants ranged from 38 to $58 \mathrm{~cm}$ in height (depending on planting date) and were 4 to $21 \mathrm{~cm}$ shorter than 'Flamenco Blue' and 'Yodel White'. 'Maurine Blue' flowered 87 and 120 days following sowing on 13 June and 13 Dec., respectively. 'Maurine Blue' can be considered an early flowering cultivar since it flowered earlier than typical commercial cultivars, such as 'Flamenco Blue' or 'Yodel White'. and 'Heidi Deep Blue' were planted 5 Jan. 1995 at Bradenton and 17-day-old seedlings were grown at a constant $31^{\circ} \mathrm{C}$ for 5 weeks, no 'Maurine Blue' plants rosetted. However, all 'Blue Lisa' and 'Heidi Deep Blue' plants were

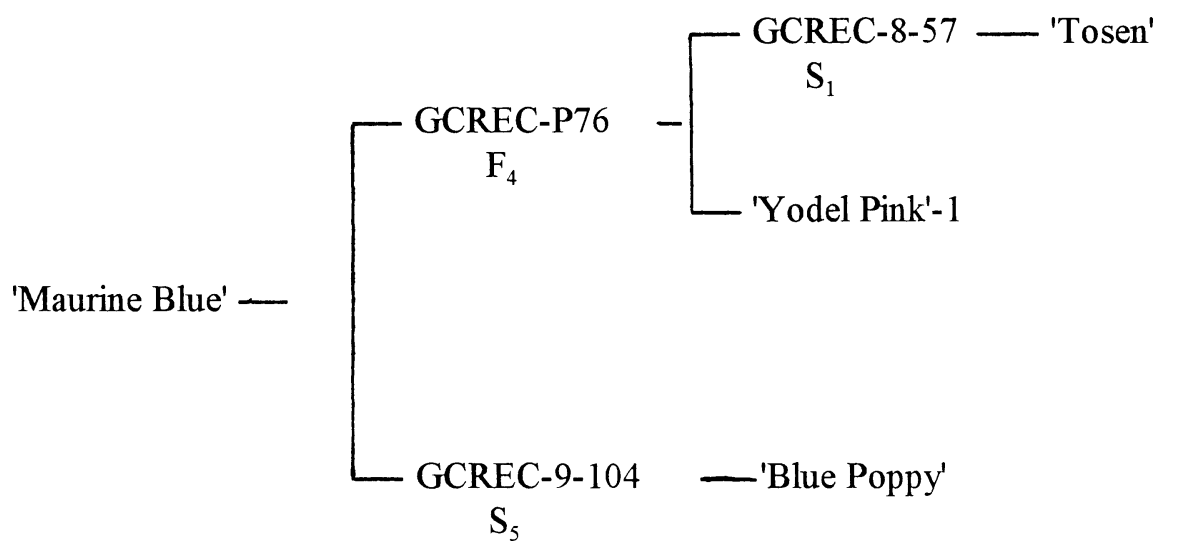

Fig. 1. Pedigree of 'Maurine Blue' lisianthus. type" display of some cut flowers that concentrate most of the flowers on the top of the plant. Flowers are bell-shaped when open with a petal length of $5.5 \pm 0.1 \mathrm{~cm}$. When flowers first open, petals are violet-blue [Royal Horticultural Society (RHS) violet-blue group 89C; RHS, 1966] on the adaxial petal surface, diffusing to a variegated $1.8 \pm 0.2-\mathrm{cm}$ white band (RHS white group 155C) at the base of the petals. As flowers mature, petal color darkens to violet (RHS violet group 86A) and the white band fades or completely disappears. The abaxial petal surface is a lighter violet (RHS violet group $86 \mathrm{~B}$ ). The center of the flowers (i.e., base of the petals surrounding the ovary) is a dark purple (RHS purple group 79A).

\section{Characteristics and use}

'Maurine Blue' ranged in height from 51 to $67 \mathrm{~cm}$ during 1994 and 1995 production trials in Bradenton and is intermediate in plant height when compared to commercial dwarf and cut flower cultivars. To our knowledge, it is the first heat-tolerant lisianthus cultivar of this height. 'Florida Blue', a semi-dwarf, heattolerant lisianthus cultivar, was released from our lisianthus breeding program in July 1995 (Harbaugh et al., 1996).

Growth retardants are necessary for production of 'Maurine Blue' in pots 12 to $15 \mathrm{~cm}$ in diameter. Plant height was $50 \pm 2.5 \mathrm{~cm}$ following foliar applications of butanedioic acid mono(2,2-dimethylhydrazide) (daminozide) at $5000 \mathrm{mg} \cdot \mathrm{L}^{-1}$ when plants were 5 to 7 $\mathrm{cm}$ tall and again at $2500 \mathrm{mg} \cdot \mathrm{L}^{-1} 3$ weeks later. These plants were produced in $11.5-\mathrm{cm}$ square pots $(0.65-\mathrm{L})$ provided with capillary mat irri-
When seeds of 'Maurine Blue', 'Blue Lisa',

semirosetted or rosetted (Table 2). 'Maurine Blue' plants were intermediate in height when compared to 'Blue Lisa' (a dwarf cultivar) and 'Heidi Deep Blue' (for cut flowers). There were more basal breaks (lateral stems forming from the first four to five leaf pairs before bolting) and lower breaks (lateral stems forming on the central flowering stem before the first flower bud) on 'Maurine Blue' plants compared to 'Heidi Deep Blue' or 'Blue Lisa'. 'Maurine Blue' had $40 \pm 6$ open flowers and buds $\approx 1$ week after the first flower opened.

'Maurine Blue' flowers acropetally with a "tier-type" display as opposed to the "spray-

HortScience, Vol. 31(6), OCtober 1996 


\section{Cultivar \& Germplasm Releases}

Table 1. Response of lisianthus cultivars grown under greenhouse conditions in Bradenton, Fla. (lat. $27.5^{\circ} \mathrm{N}$ ), with four planting dates from 13 Dec. 1993 to 12 Sept. 1994.

\begin{tabular}{|c|c|c|c|c|c|c|c|c|c|c|c|c|}
\hline \multirow[b]{3}{*}{ Cultivar } & \multicolumn{12}{|c|}{ Date sown } \\
\hline & \multicolumn{3}{|c|}{13 Dec. } & \multicolumn{3}{|c|}{14 Mar. } & \multicolumn{3}{|c|}{13 June } & \multicolumn{3}{|c|}{12 Sept. } \\
\hline & $\begin{array}{c}\text { Rosette }^{\mathrm{z}} \\
(\%)\end{array}$ & $\begin{array}{c}\text { Plant }^{\mathrm{y}} \\
\text { ht }(\mathrm{cm})\end{array}$ & $\begin{array}{l}\text { Days to } \\
\text { flower }^{y}\end{array}$ & $\begin{array}{c}\text { Rosette } \\
(\%)\end{array}$ & $\begin{array}{c}\text { Plant } \\
\text { ht }(\mathrm{cm})\end{array}$ & $\begin{array}{l}\text { Days to } \\
\text { flower }\end{array}$ & $\begin{array}{c}\text { Rosette } \\
(\%)\end{array}$ & $\begin{array}{c}\text { Plant } \\
\text { ht }(\mathrm{cm})\end{array}$ & $\begin{array}{l}\text { Days to } \\
\text { flower }\end{array}$ & $\begin{array}{c}\text { Rosette } \\
(\%)\end{array}$ & $\begin{array}{c}\text { Plant } \\
\text { ht }(\mathrm{cm})\end{array}$ & $\begin{array}{r}\text { Days to } \\
\text { flower }\end{array}$ \\
\hline Maurine Blue & 0 & 51 & 120 & 0 & 38 & 89 & 6 & 57 & 87 & 0 & 58 & 112 \\
\hline Flamenco Blue & --- & --- & --- & 62 & 43 & 102 & 47 & 61 & 105 & 33 & 79 & 130 \\
\hline Yodel White & 0 & 55 & 121 & 53 & 47 & 95 & 75 & 66 & 107 & 38 & 71 & 123 \\
\hline $\mathrm{LSD}_{0.05}$ & & 4 & 2 & & 5 & 2 & & 6 & 5 & & 9 & 8 \\
\hline
\end{tabular}

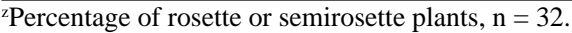

y Data on plant height and days to flower were for nonrosetted plants. Values represent the means of eight replications of single-plant experimental units arranged in a randomized complete-block design.

Table 2. Growth and flowering characteristics of lisianthus cultivars grown in 11.5 -cm square pots $(0.65-$ L) with capillary mat irrigation after exposure of seedlings to control or high temperatures. ${ }^{\mathrm{z}}$

\begin{tabular}{|c|c|c|c|c|c|c|}
\hline \multirow[b]{2}{*}{ Cultivar } & \multicolumn{2}{|c|}{ Rosette $(\%)^{\mathrm{y}}$} & \multirow{2}{*}{$\begin{array}{c}\text { Plant ht } \\
(\mathrm{cm})^{\mathrm{x}}\end{array}$} & \multicolumn{2}{|c|}{ Breaks $^{x}$} & \multirow{2}{*}{$\begin{array}{l}\text { Flowers } \\
\text { and buds }\end{array}$} \\
\hline & Control & $31^{\circ} \mathrm{C}$ & & Basal & Lower & \\
\hline Maurine Blue & 0 & 0 & 67 & 3.5 & 4.5 & 40 \\
\hline Heidi Deep Blue & 0 & 100 & 81 & 0.2 & 2.9 & 32 \\
\hline Blue Lisa & 12 & 100 & 34 & 1.6 & 2.8 & 44 \\
\hline $\mathrm{LSD}_{0.05}$ & & & 6 & 1.1 & 0.8 & 12 \\
\hline
\end{tabular}

${ }^{2}$ Seedlings were grown in a greenhouse with a high of 28 to $33^{\circ} \mathrm{C}$ day and low of 13 to $15^{\circ} \mathrm{C}$ night (control), or 17-day-old seedlings were exposed to $31^{\circ} \mathrm{C}$ for 5 weeks in a growth chamber and then flowered in the greenhouse.

yPercentage of rosette or semirosette plants, $n=24$.

${ }^{x}$ Vegetative and flowering characteristics were for nonrosetted control plants. Values represent the means of eight replications of single-plant experimental units arranged in a randomized complete-block design.

gation. Average plant height was $40 \pm 2 \mathrm{~cm}$ for 'Maurine Blue' plants treated with $(2 R S, 3 R S)$ 1-(4-chlorophenyl)-4,4-dimethyl-2-(1,2,4triazol-yl)penten-3-ol (paclobutrazol) at 0.25 $\mathrm{mg}$ a.i./pot applied as a soil drench when plants were $\approx 5$ to $7 \mathrm{~cm}$ tall.

While 'Maurine Blue' has more basal and lower branches than many commercial cultivars now forced in pots, three to four plugs per 12- to 15 -cm-diameter pot are suggested for optimal marketing display. Although this cul- tivar is intended to be used as a tall bedding plant or flowering potted plant, 'Maurine Blue' grown without growth retardants has a height suitable for the bouquet-cut flower market.

\section{Availability}

Plugs of 'Maurine Blue' will be offered for sale through Earl J. Small Growers, Pinellas Park, Fla. Scientists interested in seed for research purposes can contact B.K.H.

\section{Literature Cited}

Harbaugh, B.K. 1995. Flowering of Eustoma grandiflorum (Raf.) Shinn. cultivars influenced by photoperiod and temperature. HortScience 30:1375-1377.

Harbaugh, B.K., M.S. Roh, R.H. Lawson, and B. Pemberton. 1992. Rosetting of lisianthus cultivars exposed to high temperatures. HortScience 27:885-887.

Harbaugh, B.K., J.W. Scott, and D.B. Rubino. 1996. 'Florida Blue' semi-dwarf lisianthus [Eustoma grandiflorum (Raf.) Shinn.]. HortScience 31:1057-1058

Ohkawa, K., A. Kano, K. Kanematsu, and M. Korenaga. 1991. Effects of air temperature and time on rosette formation in seedlings of Eustoma grandiflorum (Raf.) Shinn. Scientia Hort. 48:171-176.

Ohkawa, K., T. Yoshizumi, M. Korenaga, and K. Kanematsu. 1994. Reversal of heat-induced rosetting in Eustoma grandiflorum with low temperatures. HortScience 29:165-166.

Pergola, G. 1992. The need for vernalization in Eustoma russellianum. Scientia Hort. 51:123127.

Royal Horticultural Society. 1966. Royal Horticultural Society colour chart. Royal Hort. Soc., London. 